Article

\title{
Commodity Revenues, Agricultural Sector and the Magnitude of Deindustrialization: A Novel Multisector Perspective
}

\author{
Elkhan Richard Sadik-Zada ${ }^{1,2,3, *}$, Wilhelm Loewenstein ${ }^{1,2}$ and Yadulla Hasanli 4 (i) \\ 1 Institute of Development Research and Development Policy, Ruhr-University, 44789 Bochum, Germany; \\ ieeoffice@rub.de \\ 2 Faculty of Management and Economics, Ruhr University, 44801 Bochum, Germany \\ 3 Center for Economic Development and Social Change, 80128 Naples, Italy \\ 4 Azerbaijan State Economic University (UNEC), Baku AZ1001, Azerbaijan; yadulla.hasanli@unec.edu.az \\ * Correspondence: Elkhan.R.Sadik-Zada@ruhr-uni-bochum.de; Tel.: +49-0234-322-5153
}

Received: 26 November 2018; Accepted: 15 October 2019; Published: 11 November 2019

check for updates

\begin{abstract}
This study puts forward a model of a multisector economy and embeds it in a novel theoretical framework to address the relationship between commodity revenues and manufacturing output with a special focus on the role of the agricultural sector. The three-sector model lays the groundwork for analyzing policy choices in more complex sectoral settings. Based on the theoretical analysis, the study identifies the weight of the individual economic sectors in the public revenue generation as a determinant of the magnitude of rent seeking epitomized in the crowding out effect of investments in manufacturing. We find that enclave agriculture contributes to the deindustrialization pressure in the face of natural resource windfalls. The central finding of the multisector analysis is the conclusion that not diversification per se but rather a diversification with the substantial domestic factor or market orientation has the capability to limit the magnitude of deindustrialization. For the empirical validation of the theoretical findings, the study employs fixed effects, fully modified OLS, dynamic common correlated effects estimators and dynamic fixed effects estimators for the dataset of 113 developing and transition economies for 1963-2014 period. The estimations reveal that natural resource revenues correspond with a higher level of the manufacturing sector output. In the economies with a low level of economic diversification, commodity bonanza leads however to the shrinkage of the manufacturing. In the commodity revenue dependent settings, nevertheless, agricultural sector exports have a negative impact on the performance of the manufacturing sector. These findings are in line with the predictions of the theoretical model.
\end{abstract}

Keywords: economic diversification; enclave agriculture; multisector model; developing countries; rent seeking

JEL Classification: C23; C32; D72; D73; L52; O41

\section{Introduction}

The paper at hand puts forward of a novel multisector perspective of resource curse which takes account for the level of economic diversification and patterns of interaction between natural resource rents and other sectors of economy. The proposed model develops an integrated perspective of both purely economic and institutional theories of resource curse, which, in addition, accounts for the differences in the structures of the respective economies. Incorporation of the structural context in the theoretical model, in combination with sophisticated empirical analysis enables the empirical elaboration of the model. In the framework of the empirical analysis, two main research questions are 
addressed in this inquiry. Both of them are construed from the proposed theoretical model. The first one scrutinizes the nexus between the level of economic diversification and deindustrialization in the face of commodity revenues. And the second one analyzes the contribution of the enclave agriculture to the magnitude of the resource course epitomized in the shrinkage of the manufacturing sector. To assess the corresponding research hypotheses the study employs advanced panel cointegration techniques to the dataset of 113 developing and transition economies.

The remainder of the manuscript is organized as follows: The literature review in Section 2 analyzes the existing literature on resource curse. Section 3 sets out our approach which integrates different explanations of the resource curse. Section 4 presents the multisector model of rent seeking and deindustrialization. Methodologies that underlie the survey. The Section 5 is dedicated to the estimation strategy. Section 6 deals with the data issues. Section 7 analyze the estimation results, and Section 8 concludes.

\section{Literature Review}

There is a wealth of case studies and systematic cross-country surveys suggesting that resource-abundant countries in tendency natural resource abundant countries tend to grow at a slower pace than natural resource-poor countries and exhibit inferior institutional quality (Auty and Auty 1990; Auty 1997; Sachs and Warner 1995; Gelb 1988; Havranek et al. 2016). The detrimental net growth effect of the natural resource abundance is referred to as resource curse, the staple trap, or the paradox of plenty. Since the publication of Sachs and Sachs and Warner (1995), the resource curse hypothesis belongs, despite the manifold exorcizing efforts of different authors, to one of the unabated stylized facts of our time and became enshrined in standard economic principles texts (Auty et al. 1998; Wright and Czelusta 2002; Vahabi 2017; Davis 1995; Davis and Tilton 2005). There are many different theoretical approaches to explain the resource curse phenomenon (Di John 2011; Mikesell 1997). Most of them can be classified into two groups. These are the theories putting purely economic factors as the ultimate cause of the resource curse; and institutional theories which consider the dominance of the inferior institutional quality as the primary cause of the resource curse.

The modern debate on the detrimental growth effects of commodity exports has been commenced in the late 1940s by Hans Singer and Raúl Prebisch, who argued that, in the long-run, the price of primary commodities declines relative to the price of the manufactured goods, causing deterioration of the terms-of-trade of commodity exporters. According to them, manufactured goods have a greater income elasticity of demand than crude materials. Hence, the countries focusing on manufacturing goods are expected to be the winners, and those concentrating on the commodity exports are expected to be the losers in the long term (Singer 1950; Prebisch 1950; Toye and Toye 2003). Despite its great influence in academia, this thesis, known also as the Prebisch-Singer thesis, did not find empirical vindication (Rabah et al. 2013; Cuddington et al. 2002; Balagtas and Holt 2008; Erten and Ocampo 2012; Bayramov and Conway 2010). Another purely economic argument explaining the detrimental growth effects of extractive industries goes back to Albert Hirschman (1958), who emphasized the "enclave" character of mining expressed in the lacking production linkages. A number of case studies validated this thesis for selected less developed countries with substantial mining or petroleum sectors (Rosser 2006; Teka 2011). Dutch disease is probably most prominent purely economic explanation of the resource curse. The idea of Dutch disease hypothesis has been given in Meade and Russell (1957) for a more general context and elaborated further to a sophisticated theoretical model of a commodity exporting country in Corden and Neary (1982) to address the deindustrialization experience in the Netherlands in the 1960s, after discovering huge gas deposits in the North Sea. Dutch disease model encompasses two mechanisms, how the windfalls affect the domestic tradable sector. These are appreciation of the real exchange rate (RER) of the domestic currency and resource movement effect. Due to the focus of this study on the developing economies with substantial amount of surplus labor the resource movement effect is not relevant for these countries (Brahmbatt and Otaviano 2010). The literature focusing on the natural resources-growth nexus in post-communist transition 
economies show parallels between them and developing economies, whereby surplus labor expressed in disguised unemployment is one of them. Most cross country studies and individual case studies contemplating natural resource exporting transition economies detect the negative growth effect mainly over the symptoms of Dutch disease in the petroleum exporting transition economies (Oskenbayev and Karimov 2013; Hasanov 2010; Bayramov and Conway 2010; Oomes and Kalcheva 2007; Dobryanskaya and Turkisch 2009). In the case of the Gulf countries, which are not labor surplus but rather labor shortage economies, the issue of resource movement is also less severe because of the extremely low labor intensity of the petroleum industry which dominates the extractives in the Gulf region (Sadik-Zada et al. 2019). The appreciation of the RER, in contrast is, as we shall see later, a relevant problem for the developing countries. The cross-country estimations scrutinizing the impact of the natural resources on economic growth were initiated in Wheeler (1984) and continued by a large number of sophisticated cross-sectional regressions in Sachs and Warner (1995) and a number of case studies in Gelb (1988), Auty and Auty (1990) and Auty (1997). Latest since the publication of Sachs and Warner (1995), the Dutch disease approach dominates the academic discussion on resource curse. An additional purely economic transmission channel has been suggested in Atkinson and Hamilton (2003) and Gylfason and Zoega (2006) stresses the role of investment activity in the extractives as the cause of crowding out of investments in the manufacturing sector.

There is also a considerable number of empirical investigations that analyze the growth effects of different natural resources and agricultural staples (Baldwin 1956; Lewis 1978; Isham et al. 2003). Boschini et al. (2007) go one step further and scrutinize not only the structure of the resource endowments but also delve into interaction between different resource types. In their attempt to exorcise the resource curse hypothesis, Wright and Czelusta (2002) use the positive examples of Australia, Argentina, New Zealand, Norway, and the United States, where natural resources contributed substantially to the productivity of manufacturing in the late 19th and early 20th centuries. Vahabi (2017) shows, however, that the course is mostly relevant for the areas that used to be less developed prior to the development of the extractive industries. Auty (1998) develops a critical distance to the deterministic economic models and writes, "the staple trap is a less deterministic outcome than Sachs assumes and owes more to policy choice." The attempts to explain these diverging experiences over the public choice approach can be classified into two groups. These are the rentier state theory and the theories of illicit rent-seeking (Isham et al. 2003; Leite and Weidmann 2002; Acemoglu et al. 2004; Busse and Gröning 2013; Mehlum et al. 2006). These works deliver interesting extensions of the analytical framework of Sachs and Warner (1995) and provide strong cross-country evidence that resource dependence induces negative growth effects mainly in the countries with inferior (rent-seeking) institutional quality. Country case studies conducted in Acemoglu et al. (2002) and Sala-i-Martin and Subrahamian (2003) also confirm that countries with rapacious institutions suffer more from the symptoms of resource curse than those with better institutions. Leite and Weidmann (2002) and Mauro (1995) have shown that resource abundance has an indirect negative growth effect over institutions, e.g., resources have a positive impact on grand corruption, and corruption in turn limits growth. The country case studies conducted in Acemoglu et al. (2002) and Sala-i-Martin and Subrahamian (2003) confirm the relevance of the institutions as the transmission channel of the resource curse. Leite and Weidmann (2002) and Mauro (1995) show empirically the relevance of institutions as the explanatory variables of resource curse.The models propagating the primacy of institutions epitomized in policy choices, show the conditions that have the capability to trigger the emergence of rapacious institutions and their persistence due to a greater yield than the yield of the prudent revenue management over factors like legal origin, property rights, level of the congruence between informal and formal rules, ethnic fragmentation and further factors serve as the determinants of institutional persistence in the face of commodity bonanza (Acemoglu et al. 2002; Baggio and Papyrakis 2009; Ploeg van der 2010) as in the following Figure 1. 


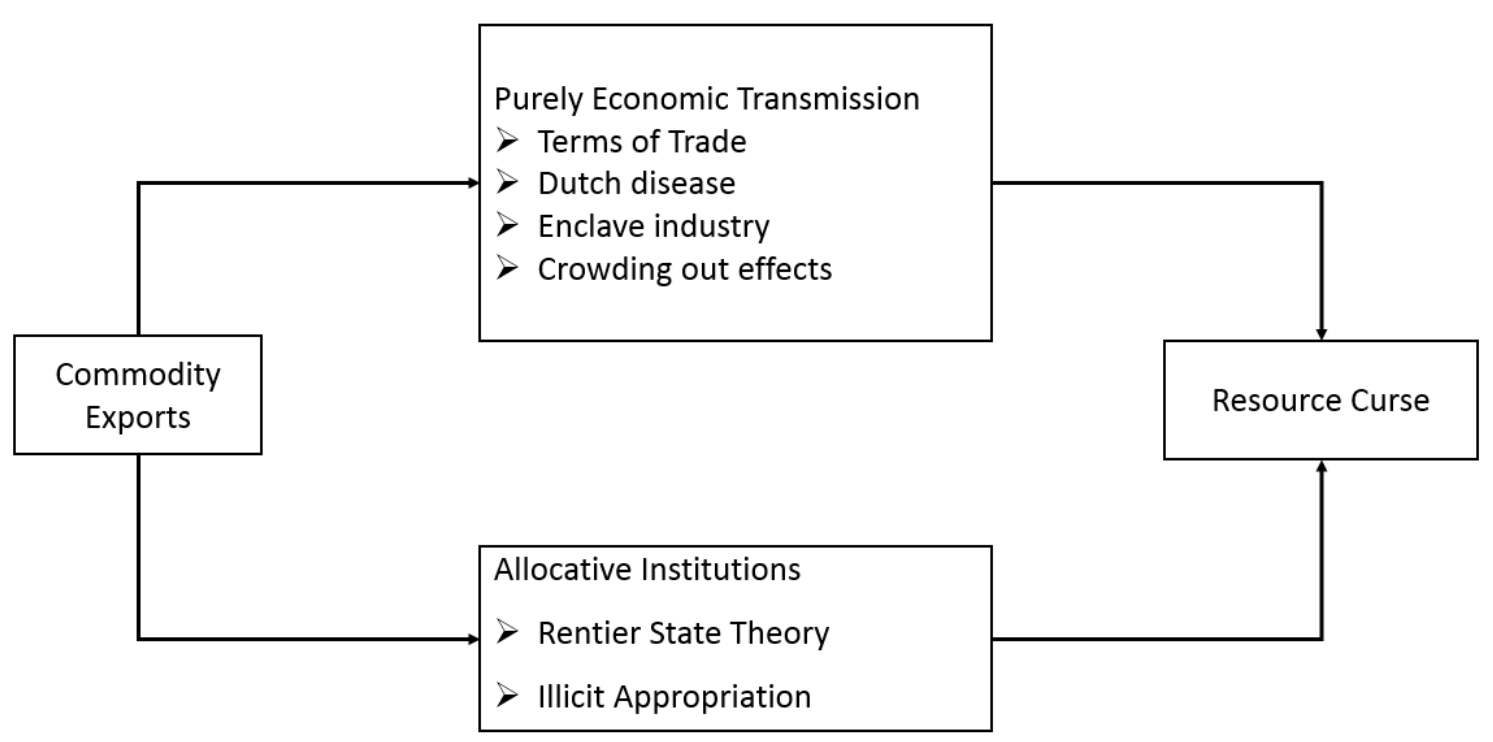

Figure 1. Transmission channels of resource curse.

Institutional incentive models undermine the cases such as Botswana, Norway, UAE and the cases of advanced economies in the late nineteenth and early twentieth centuries where natural resources fueled industrialization and the rise of the tertiary sector. All of them are, however, are mostly discrete bang-bang approaches which undermine the shift in the incentive structure towards institutional deterioration which also affects distributional institutions None of these approaches, nevertheless, addresses the magnitude of institutional deterioration and the corresponding consequences for the respective economies.

The paper at hand closes this gap by modeling institutional deterioration and deindustrialization as a continuum. To this end the study builds heavily on the assumptions of the enclave industry hypothesis, results of the institutional or political economy and Dutch disease models. We present here only a parsimonious three-sector model. These are manufacturing, extractive industries and agriculture. The extension of the model by the tertiary sector would not alter the results of the model. Thus, for the sake of simplicity, we present the model without tertiary sector.

\section{Purely Economic and Institutional Transmission Channels of Resource Curse}

Imagine we have an economic system where all the sectors are remunerated in accordance with their utility measured in the production of goods and services. The economy consists of two sectors, manufacturing and agriculture. Both sectors produce consumption goods both for the domestic and international markets. The emergence of the extractives leads to the generation of foreign currency. This currency is managed by the ruling elite. The central banks save the revenues in foreign currency then these revenues do not affect the local output in any of the sectors (Pesaran 1984). Despite the fact that macroeconomic sterilization belongs to the standard tool of the modern central banks and most natural resource reliant nations have established sovereign wealth funds (SWFs) to prevent consumptive or allocative use of the resources, recent econometric analyses find strong evidence for the appreciation pressure on the local currencies in such contexts (Hasanov 2010). SWFs have to assure that natural resource revenues are invested and not directed towards allocative projects. If so then the revenue management follows Hartwick's rule and assures a sustainable level of consumption (Hartwick 1977). Nevertheless, due to de facto dependence of the revenue management of the SWFs and monetary policies of the central banks in the developing countries fail to meet their stabilization goals (Aidt et al. 2019). The RER appreciation which owes to investments is backed by the increasing productivity and thus differs from appreciation which has been induced by the temporary increase in consumption. 
The country case studies of commodity exporting countries indicate that despite existence of the SWFs and modern macroeconomic policies, the local currencies are heavily affected by commodity revenues. Another aspect, lacking efficiency in the management of the revenues, whereby the white elephant projects crowd out investments with relatively high capital value is also one of problems, which corresponds with natural resource abundance. However, why don't the governments save the currency in the SWFs and if spend then to sub-optimal investment projects with low long run growth effects despite the fact that formally revenue sterilization and economic growth forms the fulcrum of macroeconomic policies. Are the reasons, for this kind of inefficiency are the unintended purely economic factors? This kind of problems could only be the case if the modern tools of macroeconomic policy were not known or available. Hence, we claim that the reasons for the purely economic transmission mechanisms of resource curse are not from the realm of pure economics but rather from the realm of policy choice. One of the political economy approaches to explain resource curse is the Rentier State theory (Mahdavi 1970). Rentier states rely on the natural resource exports as the major revenue source. The allocation of these revenues dominates economic relations, i.e., production, consumption, distribution and exchange. Further these are the states with overemployment in public sector with wages above their productivity, provide substantial subsidies for energy, food and selected public services (Hertog et al. 2012). This kind of policies which target the short and middle term satisfaction of the population rather than long term economic growth are in conflict with good economic policies both in the short and in the long run. Desai et al. (2009) argue that this kind of policies which target the short and middle term satisfaction of the population rather than long term economic growth can be attributed to the strategic behavior of the politicians who strive to appropriate the maximum share from the revenue for themselves in the short and middle term perspective (Sadik-Zada et al. 2019).

Rent seeking, epitomized in the rise of the allocative expenditures from the state budget leads to purely economic symptoms of resource curse. Economic problems like Dutch disease, crowding out of growth generating investments are only the symptoms of rent seeking driven bad economic policies. Thus, it is both on the theoretical and on the empirical level false, to differentiate between purely economic and political reasons of resource curse. The failure to prevent the rise of the inferior incentives is the ultimate cause of all the growth and development problems related to the notion of resource curse. If this relationship is considered then the relationship between natural resource revenues and sluggish economic growth is illustrated as in the following Figure 2.

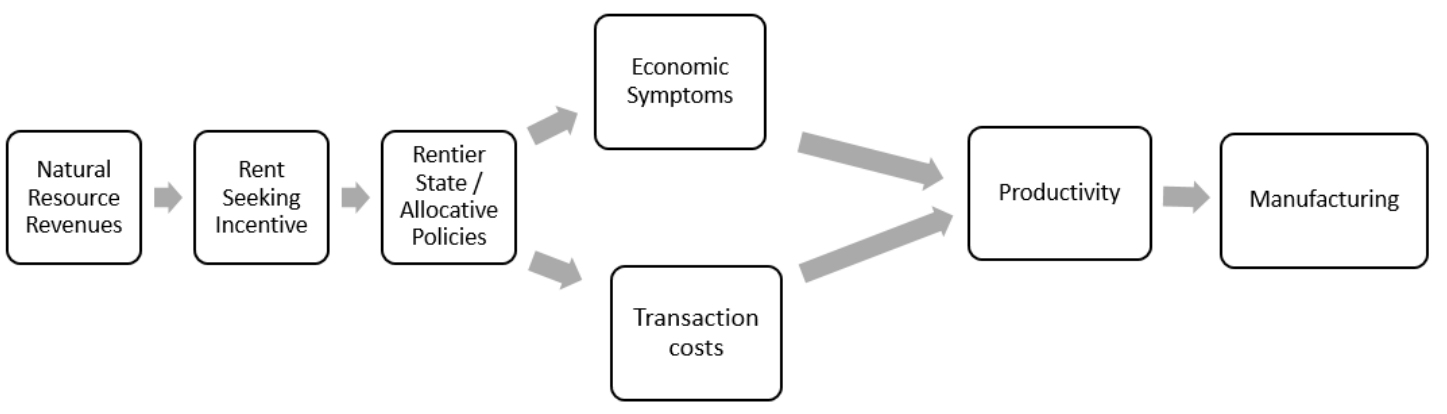

Figure 2. Integrated perspective of resource curse.

\section{A Simple Model of Rent Seeking}

It is assumed that the model economy consists of three sectors. This is a static model. Hence, we do not have to indicate the time period to which economic decisions are attributed to. These are manufacturing $(\mathrm{M})$, agriculture $(\mathrm{A})$ and extractive industries $(\mathrm{R})$. We normalize the outputs of all three sectors by assuming that one unit of manufacturing sector, agriculture and extractives have the same price, $p=1$. We denote the quantity of the output of the respective sectors by $Y_{M}$ for the manufacturing sector, $Y_{A}$ for the output of agricultural sector, and $R$ is the quantity of the extracted and exported natural resources. Manufacturing and agriculture are taxed by the politicians. There is a unified tax on 
the output of manufacturing and agriculture, $\tau$. The export revenues generated in the extractives flow entirely into the state budget. The expenditure side of the state budget, $\bar{C}$, is assumed to be constant. $\bar{C}$ is the minimized amount of expenditures which is necessary to cover the basic costs of the public sector and subsistence needs of those who are not employed or are not capable to participate on the job market (Steger 2000). These expenditures are also important against the backdrop of political stability, i.e., keeping the citizens away from protests (Granovetter 1978; Kuran 1989). The difference between the revenue and the expenditure side of the state budget is the budget surplus, $\Psi$. Based on these assumption, $\Psi$ can be expressed as it is done in the following Equation (1):

$$
\Psi=Y_{M} \tau+Y_{A} \tau+R-\bar{C}
$$

$\Omega$ enables the politicians a leeway for investment. Substantial natural resource windfalls, nevertheless, create also rent-seeking incentives, which result in unproductive or allocative expenditures (Mahdavi 1970; Beblavi and Luciani 1987; Yates 1996; Desai et al. 2009). We denote the share of $\Omega$ that is deviated from the investment towards allocative expenditure, or even towards illicit private enrichment by $\sigma$ whereby $\sigma \in[0 ; 1]$. Implementation of this kind of expenditures, however, corresponds with additional efficiency losses and transaction costs for the whole economy (Sadik-Zada et al. 2019). The magnitude of these losses depends on institutional quality in the respective country and as we shall see in the following on the sectoral structure of the economy. Hence, the total amount of the rent-seeking expenditure, $\Psi$, can be determined in accordance with the following Equation (2):

$$
\Omega=\left(Y_{M} \tau+Y_{A} \tau+R-\bar{C}\right) \cdot \sigma
$$

Especially in the non-democratic or semi-democratic political systems whereby the institutions that are supposed to ensure transparency and accountability of the rulers are defect, the rate of the rent-seeking gain, $\sigma$, is set in a way that enables the maximization of rent. To find the condition for a rent-maximizing $\sigma$, the following first-order condition (FOC), $\frac{\partial \Omega}{\partial \sigma}=0$ has to be fulfilled, i.e.,

$$
\frac{\partial \Omega}{\partial \sigma}=\frac{\partial Y_{M}}{\partial \sigma} \sigma \tau+Y_{M} \tau+\frac{\partial Y_{A}}{\partial \sigma} \tau+Y_{A} \tau+R-\bar{C}=\mathbf{0}
$$

Based on this FOC, the rent-seeking elasticity of the manufacturing sector (RSEM), $\frac{\partial Y_{M}}{\partial \sigma} \frac{\sigma}{Y_{M}}$, which indicates the magnitude of damage to the manufacturing sector owing to rent-seeking, is easily derived:

$$
\frac{\partial Y_{M}}{\partial \sigma} \frac{\sigma}{Y_{M}}=-1-\frac{R-\bar{C}}{\tau Y_{M}}+\left[-\frac{Y_{A}}{Y_{M}}-\frac{\partial Y_{A}}{\partial \sigma} \times \frac{\sigma}{Y_{M}}\right]
$$

whereby the third term $\left[-\frac{Y_{A}}{Y_{M}}-\frac{\partial Y_{A}}{\partial \sigma} \times \frac{\sigma}{Y_{M}}\right]$ is entirely attributable to the existence of the agricultural sector. Without agricultural sector, RSEM equals $\left[-1-\frac{R-\bar{C}}{\tau Y_{M}}\right]$. Whether agricultural sector leads to the confinement or enhancement of deindustrialization depends upon the sign of the third term, i.e., $\left[-\frac{Y_{A}}{Y_{M}}-\frac{\partial Y_{A}}{\partial \sigma} \times \frac{\sigma}{Y_{M}}\right] \lesseqgtr 0$. This term can also be expressed as $\left\{-\frac{Y_{A}}{Y_{M}}\left[1+\frac{\partial Y_{A}}{\partial \sigma} \times \frac{\sigma}{Y_{A}}\right]\right\}$.

The following reformulation of the Equation (4) will prove itself as useful in the following discussion of the different development scenarios with natural resource windfalls.

$$
\frac{\partial Y_{M}}{\partial \sigma} \frac{\sigma}{Y_{M}}=-1-\frac{R-\bar{C}}{\tau Y_{M}}-\frac{Y_{A}}{Y_{M}}\left[1+\frac{\partial Y_{A}}{\partial \sigma} \frac{\sigma}{Y_{A}}\right]
$$

Thus, if the rent-seeking elasticity of agricultural sector (RSEA), $\frac{\partial Y_{A}}{\partial \sigma} \times \frac{\sigma}{Y_{A}}<-1$ then the existence of this sector limits deindustrialization. If $\frac{\partial Y_{A}}{\partial \sigma} \times \frac{\sigma}{Y_{A}} \in[0,-1)$ then agricultural sector is less sensitive to the changing quality in governance and thus leads to greater for deindustrialization, epitomized in the magnitude of damage for the manufacturing sector. 
Hence, an agricultural sector output which is more vulnerable to the quality of domestic governance leads to more revenue shortage in the face of rent-seeking and contributes to the confinement of the rent-seeking tendencies. A more governance-resilient agriculture, in contrast, enhances the shrinkage of the manufacturing sector, whereby the magnitude in both cases depends upon the ratio of the outputs of the agricultural and manufacturing sectors, $\frac{Y_{A}}{Y_{M}}$.

As the theoretical elaboration reveals, agricultural sector shapes the decision on the magnitude of the rent seeking over its responsiveness to the deterioration of the quality of governance and over its share in the generation of public revenues. Hence, there are four possible scenarios of interaction of the rent-seeking incentives, triggered by windfalls, and agricultural sector of the economy. These are illustrated in the following Figure 3. The notion of developing nation comes to its own, at least in the context of this paper, through the existence of a substantial number of surplus labor (Lewis 1964). This holds also for most non-EU transition economies (Sadik-Zada 2016). Thus, in the following discussion of the possible interaction scenarios we scrutinize only the cases with surplus labor supply. The first scenario contemplates the case of a developing country with an export-oriented intensified agriculture which depends mostly on the price developments on the global crop markets and less on the local demand. This is especially typical for the cases of enclave plantation agriculture (Dietz 1985). This kind of agriculture employs more pesticides, agricultural machinery and high-tech logistics than small or medium-sized farms. These large agricultural producers have often the features of an enclave with no or only slight production and employment linkages for the local economy (Hirschman 1958). In the same time, world market-oriented intensive agriculture is more resilient towards rent-seeking tendencies than small-sized farms or mostly local market oriented manufacturing. This implies a relatively small elasticity of agriculture with regard to rent seeking, i.e., $\frac{\partial Y_{A}}{\partial \sigma} \times \frac{\sigma}{Y_{A}}$. In terms of the Equation (5) a small elasticity is an elasticity which belongs to the interval $[-1,0]$. This means that an increase of the rent-seeking share from the budget by one percentage leads to less than one percentage decrease of the output generated in the agricultural sector. As a result the third term of the Equation (5), $\left[-\frac{Y_{A}}{Y_{M}}\left[1+\frac{\partial Y_{A}}{\partial \sigma} \times \frac{\sigma}{Y_{A}}\right]\right]$, has a negative sign. Despite a relatively low value of $\left[1+\frac{\partial Y_{A}}{\partial \sigma} \times \frac{\sigma}{Y_{A}}\right]$, if the share of agricultural output exceeds the manufacturing sector, i.e., if $\frac{Y_{A}}{Y_{M}}>1$ then this also enhances the pressure of deindustrialization on the manufacturing sector. This is why, in the face of the export-oriented and resilient agriculture, the manufacturing in the countries with weak industrial base suffer more under revenue bonanza than in the case of the economies with a relatively solid industrial base. Now, we have delineated the first scenario with a resilient and large agricultural sector. The second scenario, whereby agriculture despite its resilience does not occupy a substantial position in the generation of revenues, this negative impact on the manufacturing sector is less. Because, a small $\left[\frac{Y_{A}}{Y_{M}}\right]$ leads to the decrease of the effect on the level of deindustrialization.

The third scenario is a situation whereby small-sized farms are sensitive to the rising rent-seeking tendencies and generate a substantial share of budget revenues. The existence of this kind of sector limits rent-seeking tendencies, because $\frac{\partial Y_{A}}{\partial \sigma} \frac{\sigma}{Y_{A}}<-1$ corresponds with the positive last term in the Equation (5) and a greater $\left[\frac{Y_{A}}{Y_{M}}\right]$ corresponds with a greater absolute value of this positive impact.

The fourth scenario is related to the settings with predominantly subsistence agriculture. Subsistence agriculture does not generate substantial tax revenues and is more vulnerable to the problems related to bad governance or land grabbing than large scale farms (Loewenstein and Bender 2017). This is why, subsistence agriculture does not have any impact on deindustrialization in the context of the Equation (5), i.e., $\frac{Y_{A}}{Y_{M}} \rightarrow 0$. Deindustrialization impulses, nevertheless, could protract the process of agricultural development by protracting the process of agricultural modernization (Sadik-Zada et al. 2019). 


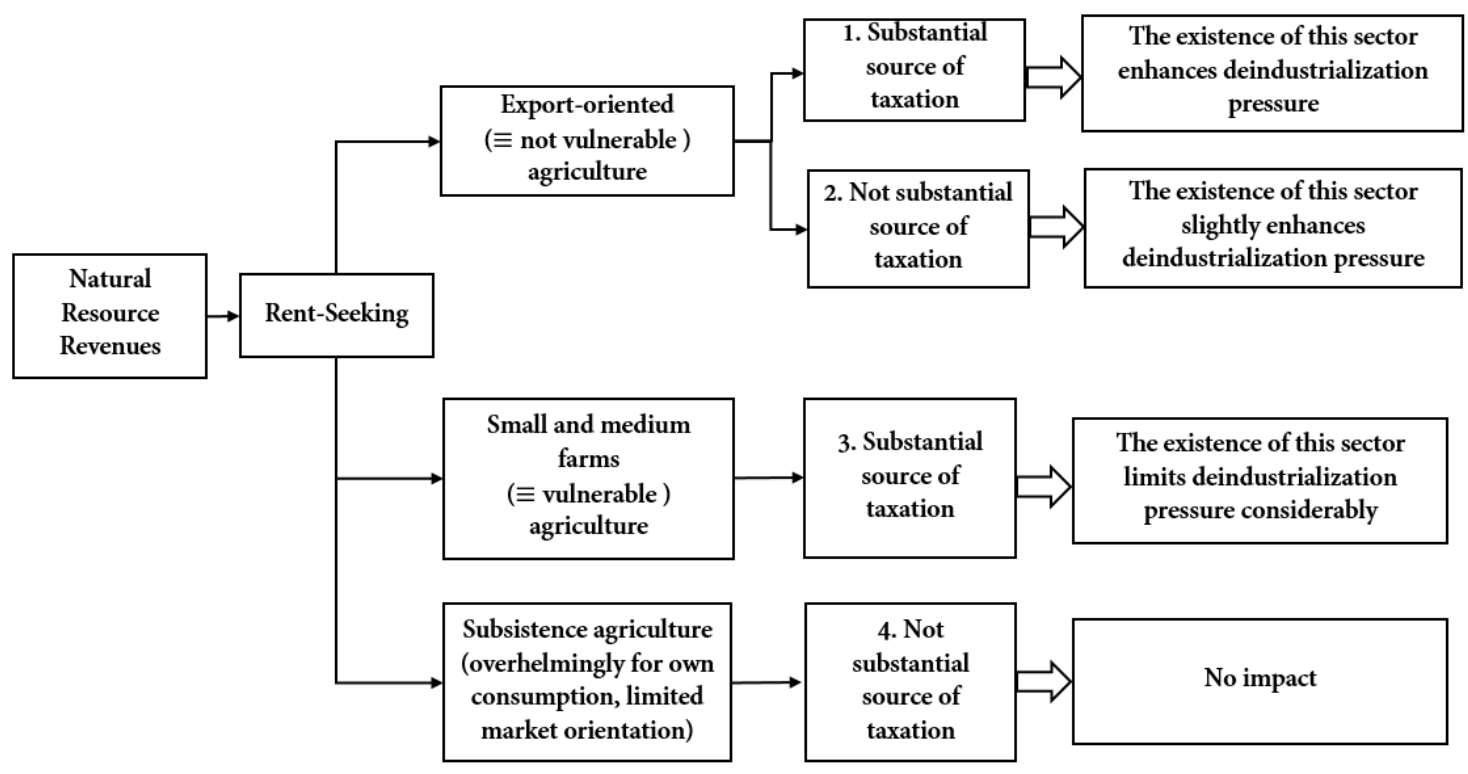

Figure 3. Interaction scenarios between agricultural sector and the degree of rent seeking.

The theoretical model presented above reveals that different organizational forms and material basis of the agricultural sector leads to entirely different outcomes with regard to the development impulses triggered from the extractive industries. Economic diversification which owes to enclave agriculture contributes to the negligence towards manufacturing sector, i.e., increasing rent seeking tendencies, in the face of the natural resource abundance. Linkage agriculture, in contrast, limits the magnitude of rent seeking and deindustrialization.

\section{Estimation Strategy}

Identification of rent seeking as the primary cause of resource curse have grave methodological consequences for the econometric analysis. The usual compartmentalization of the factors determining the magnitude of the resource curse, appreciation of the real exchange rate, institutional quality are interrelated. Employing them as explanatory variables in a specification with productivity indicators or manufacturing sector development as dependent variable is a flawed approach because of the collinearity between independent variables. Hence, only the bivariate relationship between primary cause and the outcome, i.e., the natural resource revenues and the indicators of deindustrialization makes sense if resource curse hypothesis is to be tested. Additional explanatory variables could improve the overall fit of the model. Nevertheless, these should not be the proxies for the in-between elements of the phase diagram in Figure 2. To account for the different outcome of the commodity revenues in different sector and commodity dependence settings the study employs dummy variables approach.

The econometric specifications read as follows:

$$
\begin{array}{r}
\ln M V A_{i t}=a_{j}+d_{j} t+\beta_{j 2} \text { Diversification }_{j t}+\beta_{j 3} \text { Resource_Dependence }_{j t}+ \\
\text { Interaction_Resources\#Diversification }{ }_{j t}+\gamma X_{i j}+u_{i j} \\
\ln M V A_{i t}=a_{j}+d_{j} t+\beta_{j 2} \text { Enclave_Agr }_{j t}+\beta_{j 3} \text { Resource_Dependence }_{j t}+ \\
\text { Interaction_Resources\#Enclave } e_{A g r}+\gamma X_{i j}+u_{i j}
\end{array}
$$


where $a_{j}$ denotes country-specific fixed effects, $d_{j} t$ considers the heterogeneous country-specific deterministic trends, $\ln _{-}$Diversification ${ }_{j t}$ is Theil index of export diversification; Resource_Dependence is a dummy variable which differentiates between countries that rely on commodity revenues in the generation of GDP. As a threshold 20 percent has been chosen. Countries with more than 20 is the natural logarithm of the total natural resource revenue, $\ln \_$Enclave_Agriculture ${ }_{j t}$ is the second control variable which indicates the share of agricultural exports in total exports for countries $j=\overline{1, J}$ and time periods $t=\overline{1, T}$. The major focus of this study is, nevertheless, on the bivariate relationship between income inequality and fine wine imports. The advantage of the parsimoniousness of the model is that the broad number of country-specific time-irreversible factors are captured by the country-specific deterministic factor. The same holds for $\mu_{i j}$ with respect to the unobserved common factors (Calvancanti et al. 2011). To check the robustness of the fixed effect models and to account for mixed stationarity of the underlying data the study employs Dynamic Fixed Effects. The panel consists of 118 developing and transition economies. To this end, the study employs also the Fully Modified OLS estimator which accounts more than dynamic fixed effects estimators for panel heterogeneity. To account for cross-sectional dependence arising from common factors or shocks the study also employs common correlated effects type autoregressive distributed lag estimator (CS-ARDL).

\section{Data}

To assess the validity of the multisector model of rent seeking we employ Theil index of export diversification as the measure of diversification. Theil index accounts both for the increase in the number of export products or trading partners and the shares of export volumes across active products or trading partners (IMF 2019). This index is available for 204 countries for the time period between 1963 and 2014. As the measure of global market orientation of the agricultural sector and its relative weight in the generation of aggregate revenue the study employs the share of the agricultural raw material exports as the share of merchandise exports. Agricultural raw material exports do not have substantial linkage effects for the domestic food processing and other manufacturing and if substantial then mostly have the features of an enclave. The data is available for 184 countries for the time period between 1960 and 2018. To differentiate between natural resource dependent and natural resource independent countries we employ a dummy variable, Nat1, which splits the countries between those generating more than 20 percent of their gross domestic product over the export of the natural resources and those generating less than 20 percent of their GDP over the exports of the natural resources. This data is also available over the World Bank (WB) World Development Indicators (WDI). To account for the differences in the effect of the diversification and enclave agriculture in the commodity reliant and commodity independent settings, the survey employs the interaction variables, IntNR_Divers and Int_EnclaveAgr. As the measure of the manufacturing sector the study employs manufacturing value added in constant 2010 USD provided also by WDI 2019. MVA contemplates the industries, which belong to the International Standard Industrial Classification (ISIC) divisions 15-37 (Table 1). 
Table 1. Description of data.

\begin{tabular}{|c|c|c|}
\hline Variable & Description/Transformation & Source \\
\hline Diversity & $\begin{array}{l}\text { Theil index of export diversification. A higher value } \\
\text { of index indicates a lower level of export } \\
\text { diversification. The data is available for the time } \\
\text { interval between } 1963 \text { and } 2014 \text {. }\end{array}$ & IMF (2019) \\
\hline$L n \_M V A$ & $\begin{array}{l}\text { Manufacturing value added encompasses the } \\
\text { absolute value of the output of the industries, which } \\
\text { belong to the International Standard Industrial } \\
\text { Classification (ISIC) divisions 15-37. The variable is } \\
\text { employed as a natural logarithm in the estimations. }\end{array}$ & World Bank (2019) \\
\hline Nat1 & $\begin{array}{l}\text { A dummy variable which indicates natural resource } \\
\text { dependence. } 1 \text { indicates that more than } 20 \text { percent of } \\
\text { GDP is attributed to the exports of the natural } \\
\text { resources. } 0 \text { indicates that export revenues generate } \\
\text { less than } 20 \text { percent of GDP. }\end{array}$ & World Bank (2019) \\
\hline $\ln N R e v$ & $\begin{array}{l}\text { Absolute value of the total natural resource revenue } \\
\text { as a share of GDP multiplied by GDP in constant } \\
2010 \text { USD. }\end{array}$ & World Bank (2019) \\
\hline AgrExports & $\begin{array}{l}\text { The share of the agricultural raw materials in total } \\
\text { merchandise exports. }\end{array}$ & World Bank (2019) \\
\hline Inter_NR_Diversity & $\begin{array}{l}\text { An interaction term of the Nat1 and the level of } \\
\text { export diversification. }\end{array}$ & IMF (2019) \\
\hline L. Inter_NR_Diversity & First lag of Inter_NR_Diversity & World Bank (2019) \\
\hline Inter_Ag_Nat & $\begin{array}{l}\text { An interaction term of the level of enclave agriculture } \\
\text { and dependence on the natural resource revenues. }\end{array}$ & World Bank (2019) \\
\hline
\end{tabular}

\section{Estimation Results}

The first two models in Table 2 are based on the first econometric specification in Equation (1) and analyze the impact of economic diversification on the level of the manufacturing value added. These are fixed effects models. Both estimations show that a higher level of export diversification corresponds with a higher level of the manufacturing value added. If the Theil index increases by one unit then MVA decreases by 38.9 to 40.00 percent. Natural resource export revenues per se have a statistically significant positive impact on $M V A$, whereby one percentage increase of revenues leads to 0.56 percentage increase of MVA. Model (1) and (2) we analyze the interaction of the natural resource revenue dependence and the level of economic diversity. Both models yield a statistically significant and negative effect. This implies that in the resource dependent settings more diversification leads to a higher level of the $M V A$, i.e., one percentage more of diversification leads to 6.5 to 23.9 percentage more MVA. To account for mixed stationarity, i.e., the mixture of the I (0) and I(1) time series, panel heterogeneity, endogeneity and cross-sectional dependence mentioned in Section 4, the study employs also a dynamic common correlated effects estimator, the CS-ARDL.

CS-ARDL estimators assess both short- and long-run effect of diversification on the level of manufacturing output. The CS-ARDL estimator of Model 3 yields that the increase of Theil index by one unit leads to 52.23 percentage more manufacturing sector output in the long and 32.9 percentage more output in the short run. Further CS-ARDL estimations reveal also a negative long-run effect of the natural resource dependence on MVA. Nevertheless, CS-ARDL estimators do not find any statistically significant difference in the effects of diversification in the natural resource dependent and independent countries. These estimations are available upon request. 
Table 2. Fixed Effects, FMOLS and Dynamic Fixed Effects statistics, 1963-2014.

\begin{tabular}{|c|c|c|c|c|c|c|c|}
\hline & (1) & (2) & (3) & (4) & (5) & (6) & (7) \\
\hline $\begin{array}{l}\text { Dependent Variable: } \\
\text { Natural Log MVA }\end{array}$ & $\begin{array}{l}\text { Fixed } \\
\text { Effects }\end{array}$ & $\begin{array}{l}\text { Fixed } \\
\text { Effects }\end{array}$ & CS-ARDL & $\begin{array}{l}\text { Fixed } \\
\text { Effects }\end{array}$ & $\begin{array}{l}\text { Fixed } \\
\text { Effects }\end{array}$ & FMOLS & $\begin{array}{l}\text { Dynamic } \\
\text { Fixed } \\
\text { Effects }\end{array}$ \\
\hline Diversity & $\begin{array}{c}-0.389 * * * \\
(0.0314)\end{array}$ & $\begin{array}{c}-0.400 * * * \\
(0.0305)\end{array}$ & $\begin{array}{l}-0.523 * \\
(0.2908)\end{array}$ & & & & \\
\hline $\ln N R e v$ & $\begin{array}{l}0.562 * * * \\
(0.0211)\end{array}$ & $\begin{array}{l}0.551^{* * *} \\
(0.0209)\end{array}$ & & $\begin{array}{l}0.721 * * * \\
(0.0184)\end{array}$ & $\begin{array}{l}0.714^{* * *} \\
(0.0190)\end{array}$ & & \\
\hline Nat1 & $\begin{array}{l}0.731^{* * *} \\
(0.294)\end{array}$ & $\begin{array}{l}-0.232^{* * *} \\
(0.0699)\end{array}$ & & $\begin{array}{l}-0.568^{* * *} \\
(0.0640)\end{array}$ & $\begin{array}{l}-0.553 * * * \\
(0.0677)\end{array}$ & $\begin{array}{l}-0.677^{* * *} \\
(0.1289)\end{array}$ & $\begin{array}{c}0.1676 \\
(0.3700)\end{array}$ \\
\hline $\begin{array}{c}\text { First Lag } \\
\text { Inter_NR_Divers }\end{array}$ & & $\begin{array}{l}-0.0659^{* * *} \\
(0.0127)\end{array}$ & & & & & \\
\hline $\begin{array}{l}\text { Natural Log Agricultural } \\
\text { Raw Materials Exports }\end{array}$ & & & & $\begin{array}{l}0.0488^{* * *} \\
(0.0146)\end{array}$ & $\begin{array}{l}0.0542^{* * *} \\
(0.0151)\end{array}$ & $\begin{array}{l}-0.0607^{* * *} \\
(0.005)\end{array}$ & $\begin{array}{l}-0.069 \\
(0.956)\end{array}$ \\
\hline Inter_NR_Divers & $\begin{array}{c}-0.239 * * * \\
(0.0608)\end{array}$ & & & & & & \\
\hline $\begin{array}{l}\text { Interaction Agricultural } \\
\text { Raw Materials Exports } \\
\text { and Natural Resource } \\
\text { Revenue Dependence }\end{array}$ & & & & $\begin{array}{c}-0.0427^{* *} \\
(0.0197)\end{array}$ & & $\begin{array}{l}-0.2269^{* * *} \\
(0.0464)\end{array}$ & $\begin{array}{l}-0.4409 * * * \\
(0.1316)\end{array}$ \\
\hline $\begin{array}{c}\text { First Lag Interaction Agr Raw } \\
\text { Materials Exports and } \\
\text { Natural Resource } \\
\text { Revenue Dependence }\end{array}$ & & & & & $\begin{array}{l}-0.110 * * * \\
(0.0198)\end{array}$ & & \\
\hline Constant & $\begin{array}{c}8.444^{* * *} \\
(0.553)\end{array}$ & $\begin{array}{l}8.761^{* * *} \\
(0.545)\end{array}$ & & $\begin{array}{l}2.209^{* * *} \\
(0.557)\end{array}$ & $\begin{array}{l}2.298^{* * *} \\
(0.571)\end{array}$ & & \\
\hline Error Correction Term & & & & & & & $\begin{array}{c}-0.035^{* * *} \\
(0.003)\end{array}$ \\
\hline Observations & 3079 & 3073 & 1227 & 3047 & 2855 & 1977 & \\
\hline$R$-squared & 0.259 & 0.262 & 0.48 & 0.354 & 0.363 & 0.803 & \\
\hline Number of Countries & 108 & 108 & 58 & 113 & 112 & 58 & \\
\hline
\end{tabular}

Models 4 to 7 address the role of enclave agriculture. These are fixed effects panel estimations. Model 6 is a parsimonious fully modified OLS and Model 7 is the parsimonious dynamic fixed effects model (DFE) model that have been employed to account for the time series characteristics of the time series and panel heterogeneity issues (Calvancanti et al. 2011).

Model 4 and 5 reveal that natural resource revenues and agricultural sector exports have a statistically significant positive impact on MVA. Dependence on the natural resource revenues, nevertheless, has a statistically significant negative impact on the level of the MVA. Commodity dependence corresponds with 55 percent less manufacturing sector output. With regard to the role of the world market orientation of the agricultural sector the estimations show that in the natural resource dependent settings a more world market oriented agricultural sector with enclave features leads to a lower level of the MVA. One percentage increase of the agricultural raw materials exports in the natural resource dependent settings leads to 4 to 11 percentage decrease of the level of the $M V A$. Dynamic fixed effects estimator presented in Model 6 indicate that one percentage increase of the agricultural raw materials exports leads to 4.44 percentage shrinkage of the level of the MVA. The model finds no statistically significant impact of the agricultural raw materials exports and natural resource dependence on the level of $M V A$.

\section{Concluding Remarks}

This study sets out a novel theoretical perspective, which integrates all the major transmission channels of the resource curse and puts forward a theoretical model, which delves into the features 
of the sectoral structure of the respective economies and enables accounting for more contextual information. We show that it is methodologically flown to differentiate between purely economic and institutional or policy choice causes of resource curse and identify sector structure as the primary cause of the resource curse. The study closes a research gap by modeling institutional deterioration and deindustrialization not as a discrete decision model but rather as a continuum. The multisector model of resource curse is more capable to explain the diverging outcome of the natural resources of different countries and proofs on the theoretical level the primacy of the sector structure of the hypothetic economy. Commodity revenues per se have a positive impact on the manufacturing value added. A greater dependence on these revenues, epitomized in a low level of economic diversification leads and relatively large weight of the natural resource revenues in the composition of GDP leads to a greater magnitude of deindustrialization. Nevertheless, the study finds that diversification per se is not a guarantee for a low magnitude of deindustrialization. To this end, the study differentiates between inclusive and enclave agriculture. Enclave agriculture that focuses mainly on the export of the agricultural commodity exports contributes to the further shrinkage of the manufacturing sector. Agricultural sector with strong links with the domestic economy, in contrast, limits the magnitude of deindustrialization. Empirical analysis of the proposed multisector model validates these results.

The major limitation of the study is that the level of institutional development prior to commodity bonanza and the role of the tertiary sector have not been taken explicitly under consideration. The flexibility offered by the modeling approach, nevertheless, allows easily this kind of extensions. Due to the changing nature of the tertiary sector as the sector with substantial growth potential, its inclusion and assessment of its responsiveness to the changing policy choices as further sector of the hypothetic multisector model will be addressed the follow up studies.

Author Contributions: E.R.S.-Z. and W.L. contributed together to the development of the proposed theoretical model and to the writing the conceptual part of the manuscript. E.R.S.-Z. implemented econometric analysis and contributed to the writing of the empirical part of the survey. Y.H. provided data and consulted econometric analysis.

Conflicts of Interest: The authors declare no conflict of interest.

\section{References}

Acemoglu, Daron, Thierry Verdier, and James A. Robinson. 2004. Kleptocracy and Divide and Rule: A Model of Personal Rule. Journal of the European Economic Association 2: 162-92. [CrossRef]

Acemoglu, Daron, Simon Johnson, and James A. Robinson. 2002. An African Success Story Botswana. CEPR Discussion Paper No. 3219. Available online: https://ssrn.com/abstract=304100 (accessed on 15 October 2019).

Aidt, Toke, Badalyan Zareh, and Friedrich Heinemann. 2019. Vote Buying or (Political) Business (Cycles) as Usual? The Review of Economics and Statistics, 1-45. Available online: https://doi.org/10.1162/rest_a_00820 (accessed on 15 September 2019).

Rabah, Arezki, Hadri Kaddour, Loungani Prakash, and Rao Yao. 2013. Testing the Prebisch-Singer Hypothesis since 1650: Evidence from Panel Techniques that Allow for Multiple Breaks. Journal of International Money and Finance 42: 208-23.

Atkinson, Giles, and Kirk Hamilton. 2003. Savings, growth and the resource curse hypothesis. World Development 31: 1793-807. [CrossRef]

Auty, Richard M. 1997. Natural Resource Endowment, the State and Development Strategy. Journal of International Development 9: 651-63. [CrossRef]

Auty, Richard M. 1998. Social sustainability in mineral-driven development. Journal of International Development 10: 487-500. [CrossRef]

Auty, Richard M., and Richard M. Auty. 1990. Resource-Based Industrialization: Sowing the Oil in Eight Developing Countries. Oxford: Oxford University Press.

Auty, Richard M., Richard M. Auty, and Raymond Frech Mikesell. 1998. Sustainable Development in Mineral Economies. Carendon: Oxford University Press.

Baggio, Jacopo, and Elissaios Papyrakis. 2009. Ethnic diversity, Property Rights and Natural Resources. DEV Working Paper No. 15. Available online: https://ueaeprints.uea.ac.uk/18850/1/WP15.pdf (accessed on 12 October 2019). 
Balagtas, Joseph V., and Matthew T. Holt. 2008. The Commodity Terms of Trade, Unit Roots, and Nonlinear Alternatives: A Smooth Transition Approach. American Journal of Agricultural Economics 3: 1-19. [CrossRef]

Baldwin, Roger. 1956. Patterns of Development in Newly Settled Regions. Manchester School of Economics and Social Studies 24: 161-79. [CrossRef]

Bayramov, Gubad, and Patrick Conway. 2010. The Azerbaijan Producers Survey: Dutch Disease and Financial Crisis. Available online: http://www.erc.az/files/reports/Bayramov_Conway_Azerbaijan.pdf (accessed on 15 October 2019).

Beblavi, Hasim, and Giacomo Luciani. 1987. The Rentier State. London: Croom and Helm.

Boschini, Anne, Jan Petterson, and Roine Jesper. 2007. Resource curse or Not: A Question of Appriopriability. Scandinavian Journal of Economics 109: 593-617. [CrossRef]

Brahmbatt, Milan, and Canuto Otaviano. 2010. Natural Resources and Development Strategy after Crisis. Economic Premise. February issue. Washington, DC. Available online: http://:siteresources.worldbank.org/ EXTPREMNET/Resources/Economic_Premise1.pdf (accessed on 10 September 2019).

Busse, Matthias, and Steffen Gröning. 2013. The resource curse revisited: governance and natural resources. Public Choice 154: 1-20. [CrossRef]

Calvancanti, Tiago, Kamiar Mohaddes, and Mehdi Raissi. 2011. Calvancanti, Tiago, Kamiar Mohaddes, and Mehdi Raissi. Applied Economics Letters 18: 1181-84.

Corden, W. Max, and J. Peter Neary. 1982. Booming Sector and De-Industrialization in a Small Open Economy. The Economic Journal 92: 825-46. [CrossRef]

Cuddington, John T., Rodney Ludema, and Shamila A. Jayasuriya. 2002. Prebisch-Singer-Redux. In Natural Resources and Development: Are They A Curse? Are They Destiny? Edited by Daniel Lederman and Maloney William. Washington: Stanford University Press, pp. 103-37.

Davis, Graham A. 1995. Learning to love the Dutch disease: Evidence from the mineral economics. World Development 23: 1765-79. [CrossRef]

Davis, Graham A., and John E. Tilton. 2005. The resource curse. Natural Resources Forum 29: 233-42. [CrossRef]

Desai, Raj, Anders Olofsgard, and Tarik Yousef. 2009. The Logic of Authoritarian Bargains. Economics and Politics 21: 93-125. [CrossRef]

Di John, Jonathan. 2011. Is There Really a Resource Curse? A Critical Survey of Theory and Evidence. Global Governance 17: 167-84. [CrossRef]

Dietz, James. 1985. Export-Enclave Economies, International Corporations, and Development. Journal of Economic Issues 19: 513-22. [CrossRef]

Dobryanskaya, Victoria, and Edouard Turkisch. 2009. Is Russia Sick with the Dutch Disease? CERII Working Paper No. 2009-20. Available online: https://core.ac.uk/download/pdf/6290211.pdf (accessed on 18 March 2019).

Erten, Bilge, and José Antonio Ocampo. 2012. Super-Cycles of Commodity Prices since the Mid-Nineteenth Century. DESA Working Paper No. 110. Available online: http://www.un.org/esa/desa/papers/2012/wp110_2012.pdf (accessed on 15 October 2019).

Gelb, Alan. 1988. Oil Windfalls: Blessing or Curse? Oxford: Oxford University Press.

Granovetter, Mark. 1978. Threshold models of collective behavior. American Journal of Sociology 83: 1420-43. [CrossRef]

Gylfason, Thorvaldur, and Gylfi Zoega. 2006. Natural Resources and Economic Growth: The Role of Investment. The World Economy 29: 1091-115. [CrossRef]

Hartwick, John. 1977. Intergenerational Equity and the Investing of Rents from Exhaustible Resources. American Economic Review 67: 972-74.

Hasanov, Fakhri. 2010. The Impact of Real Oil Price on Real Effective Exchange Rate: The Case of Azerbaijan. Discussion Papers of DIW Berlin 1041. Available online: http://www.diw.de/documents/publikationen/73/ diw_01.c.359129.de/dp1041.pdf (accessed on 14 June 2019).

Havranek, Tomas, Roman Horvath, and Ayaz Zeynalov. 2016. Natural Resources and Economic Growth: A Meta-Analysis. World Development 88: 134-51. [CrossRef]

Hertog, Steffen, Andras Bodor, and Robert Holzmann. 2012. Labor market distortion in oil rentier states: the citizen's income and other possible solutions. IZA Conference Paper 2012. Available online: www.iza. org./conference_files/worldb2012/bodor_a5710.pdf (accessed on 11 April 2019).

Hirschman, A. 1958. The Strategy of Economic Development. New Haven: Yale University Press. 
IMF. 2019. IMF DATA. Export Diversification and Quality. Available online: http://data.imf.org/?sk=A093DF7DE0B8-4913-80E0-A07CF90B44DB\&sId=1497638692318 (accessed on 21 June 2019).

Isham, Jonathan, Michael Woolcock, Lant Pritchett, and Gwen Busby. 2003. The Varieties of Resource Experience: How Natural Resource Export Structures Affect the Political Economy of Economic Growth. The World Bank Economic Review 19: 141-74. [CrossRef]

Kuran, Timur. 1989. Sparks and prairie fires: A theory of unanticipated political revolution. Public Choice 61: 41-74. [CrossRef]

Leite, Mr Carlos, and Jens Weidmann. 2002. Does Mother Nature Corrupt? Natural Resources, Corruption, and Economic Growth. IMF Working Paper No. 99/85. Washington: International Monetary Fund.

Lewis, Arthur. 1964. Economic Growth with Unlimited Supplies of Labour. The Manchester School 22: 401-49.

Lewis, Arthur. 1978. Growth and Fluctuations. London: George Allen \& Unwin.

Loewenstein, Wilhelm, and Dieter Bender. 2017. Labour Market Failure, Capital Accumulation, Growth and Poverty dynamics in Partially Formalised Economies: Why Developing Countries' Growth Pattern are Different. SSRN Ecectrinic Journal. Available online: http://dx.doi.org/10.2139/ssrn.3022146 (accessed on 18 August 2018). [CrossRef]

Mahdavi, Hossain. 1970. The patterns and problems of economic development in rentier states. In Studies in the Economic History of the Middle East. Edited by Amy Cook. Abingdon: Routledge, pp. 407-37.

Mauro, Paolo. 1995. Corruption and Growth. Quarterly Journal of Economics 110: 681-712. [CrossRef]

Meade, J. E., and E. A. Russell. 1957. Wage rates, the cost of living, and the balance of payments. Economic Record 33: 22-23. [CrossRef]

Mehlum, Halvor, Karl Moene, and Ragnar Torvik. 2006. Institutions and the Resource Curse. Economic Journal 116: 1-20. [CrossRef]

Mikesell, Raymond F. 1997. Explaining the resource curse, with special reference to mineral-exporting countries. Resources Policy 23: 191-99. [CrossRef]

Oomes, Nienke, and Katerina Kalcheva. 2007. Diagnosing Dutch Disease: Does Russia have the Symptoms? IMF Working Paper No. 07/102. Washington: International Monetary Fund.

Oskenbayev, Yessengali, and Aziz Karimov. 2013. Is Kazakhstan Vulnerable to Natural Resource Curse? WIDER WP 2013: 130.

Pesaran, Mohammed Hashem. 1984. Macroeconomic Policy in an Oil-Exporting Economy with Foreign Exchange Controls. Economica 51: 253-70. [CrossRef]

Ploeg van der, Rick. 2010. Why do many resource-rich countries have negative genuine saving? Anticipation of better times or rapacious rent seeking? Resource and Energy Economics 32: 28-44. [CrossRef]

Prebisch, Raul. 1950. The Economic Development of Latin America and its Principal Problems. New York: United Nations.

Rosser, Andrew. 2006. The Political Economy of the Resource Curse: A Literature Survey. IDS Working Paper 268. Brighton: Institute of Development Studies.

Sachs, Jeffrey D., and Andrew M. Warner. 1995. Natural Resource Abundance and Economic Growth. NBER Working Paper No. 5398. Available online: http://www.nber.org/papers/w5398 (accessed on 14 June 2014).

Sadik-Zada, Elkhan Richard. 2016. Oil Abundance and Economic Growth. Berlin: Logos Verlag.

Sadik-Zada, Elkhan Richard, Wilhelm Loewenstein, and Yadulla Hasanli. 2019. Production Linkages and Dynamic Fiscal Employment Effects of Azerbaijani Economy: Input-Output and Nonlinear ARDL Analyses. Mineral Economics (online first). Mineral Economics, 1-16. [CrossRef]

Sala-i-Martin, Xavier, and Arvind Subrahamian. 2003. Addressing the Natural Resource Curse: An Illustration from Nigeria. IMF Working Paper 03/139. Available online: https://www.imf.org/external/pubs/ft/wp/2003/ wp03139.pdf (accessed on 14 June 2014).

Singer, Hans W. 1950. The Distribution of Gains between Investing and Borrowing Countries. American Economic Review 40: 473-85.

Steger, Thomas. 2000. Economic growth with subsistence consumption. Journal of Development Economics 62: 343-61. [CrossRef]

Teka, Zeferino. 2011. Backward Linkages in the Manufacturing Sector in the Oil and Gas Value Chain in Angola. MMCP Discussion Paper. Cape Town: University of Cape Town.

Toye, John, and Richard Toye. 2003. The origins and interpretation of the Prebisch-Singer Thesis. History of Political Economy 35: 437-67. [CrossRef] 
Vahabi, Mehrdad. 2017. A Critical Survey of the Resource Curse Literature through the Appropriability Lens. CEPN Working Papers 2017-14. Paris, France: Centre d'Economie de l'Université de Paris Nord. Available online: https://cepn.univ-paris13.fr/wp-content/uploads/2017/09/DT-CEPN-2017-14.pdf (accessed on 14 June 2014).

Wheeler, David. 1984. Sources of stagnation in sub-Saharan Africa. World Development 12: 1-23. [CrossRef]

World Bank. 2019. World Development Indicators. Available online: https://databank.worldbank.org/source/ world-development-indicators (accessed on 8 April 2019).

Wright, Gavin, and Jesse Czelusta. 2002. Exorcizing the Resource Curse: Minerals as a Knowledge Industry, Past and Present. Available online: http://www.handresearch.org/papers/263.pdf (accessed on 10 June 2019). Yates, Douglas. 1996. The Rentier State in Africa: Oil Dependency and Neocolonialism in the Republic of Gabon. Trenton: Africa World Press.

(C) 2019 by the authors. Licensee MDPI, Basel, Switzerland. This article is an open access article distributed under the terms and conditions of the Creative Commons Attribution (CC BY) license (http://creativecommons.org/licenses/by/4.0/). 